\title{
Investing in youth for a brighter tomorrow
}

\author{
Prabha Manuratne \\ Department of English, Faculty of Humanities, University of Kelaniya, Sri Lanka \\ Correspondence: pmanuratne@kln.ac.lk
}

DOI: https://doi.org/10.4038/jccpsl.v25i3.8219

Received on: 8 August 2019

Accepted on: 30 August 2019

Caught between the clutching pull of tradition and the dynamic push of change, youth stand at the crossroads of the future of their communities: sometimes with hope, sometimes with despair. Across the world, political leaders and community leaders generally tend to be older: their wisdom their asset, their maturity perhaps their fetters. In Sri Lanka, youth attempts to participate in the progress of their communities have led to a scarred history of violence. The cover story invites the readers to contemplate the possibilities and challenges we offer to youth to participate productively in society, and to engage actively in decision-making processes that affect their own lives and those of their children. This issue's cover depicts the theme of the College of Community Physicians of Sri Lanka of this year, 'Shaping a Healthy Future - Youth as a Smart Investment'.

Investing in youth has been considered a top priority by world leaders and national leaders. For example, the United Nations asserts, under its agenda for sustainable development goals, "We will strive to provide children and youth with a nurturing environment for the full realization of their rights and capabilities, helping our countries to reap the demographic dividend, including through safe schools and cohesive communities and families". Education, health, and human rights are central to the development of youth, and investing in these is a key means through which any community can nurture youths to becoming responsible and caring adults. Across the world, countries that have invested in education and

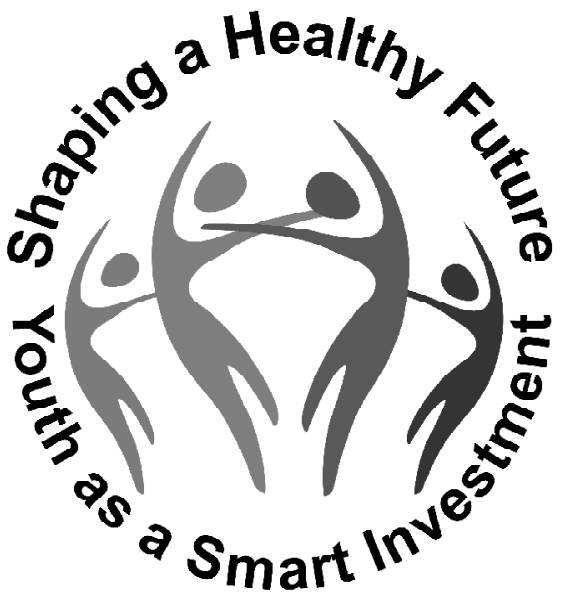
health are at the forefront of development that is both sustainable and equitable. Historically, Sri Lanka has been highly forward-thinking when it comes to investing in education and health. But Sri Lanka has been lagging in other areas such as equitable economic development that can create dynamic opportunities to offer youths to participate in society and the economy once they become healthy educated citizens. Herein lies the challenge for both adults and youths today: how can we sustain the opportunities we offer to youth to grow, but also make them meaningful, so that they lead to productive outcomes to society?

When adults crowd out the social sphere and make decisions that are destructive to society, in the long run, youths become disillusioned and indifferent, losing faith in their own capacity to make effective change. Lulled 
into indolence through ideological bubbles that are characteristic of our technocratic media culture, we often find that youth no longer feel that they have either the ability or the opportunity to participate meaningfully in society. Thus, our investment in our youth demands that we take a holistic approach, not only by investing materially in the well-being of young people, but also investing in making our societies more democratic, participatory, and open to new ideas and change. Our cultural rootedness, which is crucial to the healthy development of any society, should not be manipulated into ethno-religious myopias that trap our youth in destructive xenophobic ideologies and target certain segments of the community. Investing in youth, thus, also involves, investing in creating social conditions that foster respect, discipline, and commitment in youths who feel that they have a crucial role to play in their communities, and by extension, in this country. Beyond mere material investment, investing in youth is a process that will allow the greater humanization of young people, who strive, not only for personal development, but to recognize that they have a fundamental responsibility towards society. Youth is naïve and hopeful. That is its strength. Their vision of a better future, that is not mellowed by experience and regret that often characterize adulthood may, perhaps, help our communities to escape the deadening entrapment that causes stagnation. A brighter future always depends on our ability to dream big. To invest in youth is to give flesh to such dreams and help them choose life over death and destruction.

\section{Reference}

United Nations. Transforming our World: the 2030 Agenda for Sustainable Development. Available from: https://undocs.org/A/RES/70/1. 